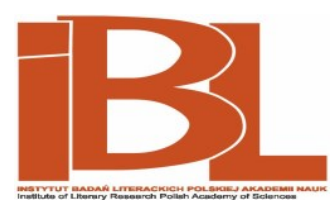

\title{
Affective Studies in Poland: Probing the Field
}

Ryszard Nycz 


\section{Foreword}

Ryszard Nycz

\section{Affective Studies in Poland: Probing the Field}

DOI: 10.18318/td.2017.en.1.1

A mong contemporary analytic cultural practices, theoretical practices (praxes), and the humanities more broadly, the field known as affect theory occupies a central, perhaps even fundamental, place. Like other theoretical orientations, this term takes its name from a key concept that serves as a guiding principle, one that not only unlocks an important dimension of our social and cultural life, but also shapes its qualities.

One cannot help but observe that this perspective tackles issues that are as old as culture and the humanities themselves, yet it does so in a manner that reorients and restructures the field of study; it generates new sub-disciplines (such as the study of emotional communities and their role in the processes that shape history and civilization) and reconfigures the positions and meanings of other key concepts in the humanities vocabulary (notably intellect, mind, experience, matter, sensuality, corporeality, etc.) in a way that invites other, hitherto unaddressed, questions - ones that can be leveled at established subjects and problems - and produces different and novel answers.

There is much to suggest that affect studies - practiced in the West for well over two decades, but a mere few years in Poland - are not a fleeting trend and have established
Ryszard Nycz - Professor at the Institute of Literary Research of the Polish Academy of Sciences and Chair of the Department of Literary Anthropology and Cultural Studies, Jagiellonian University. He is the Editor-in-Chief of Teksty Drugie. Ordinary member of the Polish Academy of Sciences and corresponding member of the Polish Academy of Arts and Sciences, The Committee on Literature Studies, and The Committee on Cultural Studies of the Polish Academy of Sciences. He recently published: Kultura jako czasownik. Sondowanie nowej humanistyki (2017). Contact: ryszard.nycz@uj.edu.pl 
a lasting foothold in the humanities. It cannot be ruled out that the theory will permeate deeper into the disciplinary and methodological traditions of the humanities, and in doing so transform our perception of their subject as well as the principles and processes by which they are determined. Philosophers of culture, sociologists, psychologists, writers and artists all assert that we live in affective societies; that we form emotional communities in which social and community bonds are founded on a shared affective amalgam (a predominantly negative one, at that: consider the "culture" of profuse hatred and "flaming" on the Internet) rather than on rational choice and recognition.

It is likely for this reason that collectively expressed and articulated feelings and emotions function in a paradoxical way: they join and separate their participants, at once uniting and dividing them. They stimulate groundbreaking and unpredictable political actions and retroactively revise the collective memory of the past. They dismiss the sterile notion of the classic subject - a rational manager of himself, his relations with others and the world - and propose instead a vision of the individual with an embodied mind, one who elicits and negotiates, rather than manages, his needs, goals, and relations with others; an individual who cocreates the community he shares with the non-human world... All of this takes place within the open horizon of sensual-affective experiences. Complementing this image of a present sensitized to affective relations is technology that will provide - if it does not do so already - applications for electronic communication devices that will display the affective stances of one's interlocutor even before his or her views have been heard.

It is apparent that a similar transformation is occurring in our perception and performance of culture, in which the emphasis is shifting from the nominal and adjectival sense (that is, a product or quality that grounds it in the "objectified heritage" of human output or depicts it as a normative system of symbolic control over human activity) to its verbal aspect. The latter stresses cultivation, or a creative activity that is directed, on the one hand, at prompting growth and the unleashing of hidden capabilities, showing respect for the value of someone or something's existence, and, on the other hand, at planning and controlling development, breeding and nurturing the desired shapes of the developed forms.

The activation of this actional aspect that is central to the etymology of culture (from cultio and colere: to cultivate, nurture, shape, celebrate) alerts us to the fact that, firstly, culture is above all else that form of creative activity that breathes life into something that would not have been realized without this external and "obstetrical" (somewhat maieutical) - and at once supervisory and managerial - intervention. Unfortunately, this process is not an unambiguously positive one; its nature can be emancipatory or colonial. It is no coincidence that culture and colony (and, by extension, colonization) share their etymology; the process of cultivation contains the possibility of either encouraging the fulfillment of potential or follow- 
ing pathways of development that hew to imposed cultural patterns and norms including ones inflicted by institutions and authorities.

Secondly, the verbal, actional concept of culture demonstrates that an inherent quality of this notion of cultural production is the affective aspect, that is, an outward-facing "inclination" toward someone or something. It does not strive to dominate the object of its attention, but simply to let it be. As testified by Słownik Warszawski (the Polish dictionary compiled by Karłowicz, Kryński, and Niedźwiecki at the turn of the 19th and 2oth centuries; old dictionaries of other languages reveal comparable meanings), aside from afekt (affect), the Polish language in the past distinguished afekcja (affection: an inclination toward someone or something) from afektacja (affectation: excess, feigned affect). Arct's loanword dictionary (published in the interwar period) additionally provides the cognate verb afekcjonować: to have a liking for something, to favor. This aspect thus involves a kind of inclination toward something or someone - our"fundamental" predisposition - that is an expression of interest in that which is outside of ourselves and our attraction to the Other, encouraging in turn the growth and being of that which is other. It allows this other to exist; it allows it to be other; it makes way for the ethics of guestotherness $^{1}$ - hospitality to the Other and his or her otherness - and responsibility (as Cezary Wodziński emphasizes visually in his elaboration on the idea proposed by Derrida). ${ }^{2}$ Unfortunately, it is this latter meaning that has displaced and replaced the former in contemporary Polish - and in contemporary culture - to the detriment of the thing itself and the manner about which it is spoken.

The cultural study of affect is concerned with both (affect and affectation), but places greater emphasis on the first: the methods of articulation and representation (and arousal, influence, organization, etc.) of affects, emotions, feelings, moods, and so on, in artistic and cultural practice. Their typology remains rather unstable and is typically specified by the context or individual and inventive definition projects. One could argue that little has changed since the original endeavors were made in this field (such as the book published by Altieri fourteen years ago ${ }^{3}$ and Deleuze's concept of affective intensity ${ }^{4}$.

1 A play on the Polish word gościnność, hospitality, which is divided here into gość, guest, and inność, otherness. [Translator's note]

See Cezary Wodziński, Odys. Esej o gościnności (Gdańsk: słowo/obraz terytoria, 2015).

See Charles Altieri, The Particulars of Rapture. An Aesthetics of the Affects (Ithaca, London: Cornell University Press, 2003).

See, for example Gilles Deleuze and Félix Guattari, What is Philosophy?, trans. Graham Burchell and Hugh Tomlinson (London, New York: Verso, 1994); Brian Massumi, Parables for the Virtual. Movement, Affect, Sensation (Durham: Duke University Press, 2002); Brian Massumi, The Politics of Affect (Oxford: Wiley, 2015); Sara Ahmed, The Cultural Politics of Emotions (London: Routledge, 2004); The Affective Turn: Theorising the Social, ed. Patricia Ticineto Clough and Jean 
The list of problems "opened up" by this new theoretical dictionary is in fact much longer. To avoid a more detailed and lengthy discussion, let us mention three that are likely the most problematic: (1) are affects (in their myriad forms, modalities, and combinations) represented in texts and other cultural objects, or are they articulated by other, nonrepresentational means of expression, including via negativa, that is, by way of gaps, interstices, or the interference of discursive or artistic organization; (2) are affective "meanings" (like the "meanings" conveyed in images) separate modes of communication, or can they be examined within the limits of a broader understanding of the semantic values of the cultural text; (3) can the intellect-affect relationship be regarded as a binary opposition, or are we to pursue a new way of conceptualizing it; if so, what would this new approach entail? As can easily be surmised, the arguments invariably point to the latter of the two positions.

Whether the broad range of scholarship initiated by affective studies deserves to be described as yet another "turn" (a periodization label that has depreciated significantly) - or is simply the latest in a series of cultural studies "vocabularies" is likely of little importance. What is worthy of notice, however, is that it effectively serves the same methodological purpose. If, as Bachmann-Medick observes, ${ }^{5}$ turns are revealed by their use of conceptual vocabularies not just to identify and describe (new) objects, but as entirely new analytical categories - methodical operational procedures that alter the established ways of describing the object of study, identifying new features, dimensions, and functions of the reality being explored - then affective studies undoubtedly fulfill these requirements.

They are used not only to study new qualities (or "intensities") of contemporary culture, but also - and perhaps primarily - to reinterpret the outdated image of past humans, societies, and cultures. And, as is often the case with such attempts at revolutionary reinterpretations, they dispense rather unceremoniously with the existing body of knowledge and nuanced, multi-perspectival views on the field of study. They appear at first glance to often propose a single "affective" point

Halley (Durham, London: Duke University Press, 2007); Sianne Ngai, Ugly Feelings (Cambridge: Harvard University Press, 2007); Formy aktywności umysłu. Ujęcia kognitywistyczne. Vol. 1: Emocje, percepcje, świadomość, ed. Andrzej Klawiter (Warszawa: Wydawnictwo Naukowe PWN, 2008); Anne Hochschild, The Managed Heart: Commercialization of Human Feeling (Berkeley: University of California Press, 2012); Emocje w kulturze, ed. Małgorzata Rajtar and Justyna Straczuk (Warszawa: Wydawnictwa Uniwersytetu Warszawskiego, 2012); The Affect Theory Reader, ed. Melissa Gregg and Gregory J. Seigworth (Durham, London: Duke University Press, 2012); Kultura afektu - afekty w kulturze. Humanistyka po zwrocie afektywnym, ed. Ryszard Nycz, Agnieszka Dauksza and Anna Łebkowska (Warszawa: IBL PAN, 2015); Teksty Drugie 6 (2013), 1 (2014) (essays on the subject of affect).

5 Doris Bachmann-Medick, Cultural Turns. New Orientations in the Study of Culture, trans. Adam Blauhut (Berlin, Boston: De Gruyter, 2016). 
of view, narrowly profiled toward the interpretation of a given discipline, system, artistic current, or genre, only to cast in even starker relief the cognitive benefits of this undertaking (even at the cost of presenting an incomplete or biased image). Viewed from this perspective, they can be said (for now) to be mere scholarly manifestos announcing new cognitive standpoints in the public reflection of the humanities on culture and new outlooks therein, rather than meticulous investigations, nuanced conjectures, or robust, argument-driven adjustments to the established image of culture.

On the other hand, however, these incomplete findings, scholarly probes, and analytic inquiries are gradually changing the existing cultural landscape, its perception, the nature of the theoretical and analytic practice, and the prevailing views concerning its nature. Not only do they imply the legitimacy of examining culture through its affective dimension, they also encourage the conclusion that we are now entering "affective culture," that is, a contemporary culture whose distinguishing features stem in large part from its "investment" in affective relations that determine the dominating forms of art and literature, leaving an unmistakable mark on the preferred types of attitudes and behaviors, and on the preferred institutional strategies for organizing and managing the "experience society" whose arrival was heralded long ago by Gerhard Schulze. ${ }^{6}$

Furthermore, upon closer examination, this "affective culture" acquires meanings that prevent it from being placed within the standard dualities of modern thought. One might say that it is located in a sort of "non-place" in the traditional vocabulary of the humanities, as it transcends the oppositions of nature and nurture, intellect and emotion, the individual and the community, the linguistic and the extra-linguistic, the semantic representation of concepts and the sensual experience... seizing a tremendously rich and diverse spectrum of affective excitements and reactions, which take the form of affects, emotions, feelings, moods... that activate in various media, forms, and genres of high ("elite") and popular culture.

This brings us to another significant aspect of affective studies, aside from its preoccupation with affective states and processes in their relationships with other human organs, senses, faculties, and predispositions: namely, the projection of affective readings (as well as the affective perception and cognition) on all sorts of objects. This can be likened to the psychological, sociological, or semiotic practice of "framing." Affective framing directs our attention, allowing us to identify the desired objects and goals, and select the appropriate strategy with which to accomplish the task... At the same time, the process of affective framing is general in nature: it involves directing our attention to an "exciting" element (phenomenon,

6 See Gerhard Schulze, Die Erlebnisgesellschaft. Kultursoziologie der Gegenwart (Frankfurt am Main: Campus, 1992). On this subject, see also Scott Lash, Another Modernity. A Different Rationality (Oxford: Blackwell, 1999). 
event, or thought), isolating it from others, intensifying it, performing a value judgment and the re-hierarchization of its qualities, and correlating it with other elements with which it forms a sort of constellational whole or figure.

In this manner, the process can describe not only techniques for organizing the emotional impact of popular or elite art, but also the broad development of new cultural texts or even theoretical discourses in the humanities, particularly at the stage of incomplete crystallization, exploration, or the search for systemic regularities among the amalgam of phenomena encountered in experience - that is, when the theory is at the stage of "practicing theory" or "theory in practice." It is also in this territory - the scholarly discourse of the humanities - that affect first operates as the Spinozian conatus: as an impulse or stimulator of attention, which then activates, profiles, and organizes cognitive processes in close ties with the environment.

The theoretical practices of new currents in the humanities (in such fields as the engaged humanities, posthumanism, and enactivism) undoubtedly make deliberate use of this affective tool in their critical explorations: they excite and direct our attention; they create perceptive-cognitive frames that structure the organization of components according to their implicit value; they activate audiences, influencing their attitudes, mentality, behavior, and actions. The discourse of these new humanities is affective in the aforementioned sense and for more fundamental reasons: it is excited and energized by its inherent affection - its inclination to act for the good of the other, an inclination that combines affective stirring with cognitive curiosity and ethical sensitivity.

I propose that this method of cognitive action - a dominant one among the procedures of inquiry employed in the new humanities - be called probing, as it is to a certain extent a unique methodical tactic. It has several distinct features that distinguish it from the standard methods associated with the humanities. Firstly, it involves studying the environment in question from within, in the field of a mutually shared experience. Secondly, it relies on the tentative, selective penetration of the problematic territory, typically through the study of specific cases. Thirdly, its preferred technique is the peculiar "plying" of objects, events, and processes with questions and experimental interventions, enabled by new conceptual vocabularies, thus eliciting and presenting hitherto imperceptible qualities of the object of study.

This issue presents a selection of essays from the field of affective studies in Poland, spanning - and probing - nearly all the disciplines and orientations within the humanities today. The texts deal with matters ranging from philosophy to the overlapping domains of the sociological and cultural, the political and psychoanalytical, the ethnographic and anthropological, and the aesthetic and theoretical. They comprise studies in the fields of literature and film, theater and gender studies, memory studies and Holocaust studies, focusing on analyses of key complex 
affects, such as love, shame, and guilt, as well as on their transformations and the flows of affective "intensities," which often remain in the state of amalgamative indeterminacy.

Considering the sheer diversity of subjects and methodologies contained within this brief selection of texts, I believe they provide a decent introduction to the field of affective studies in Poland at their current stage of development. They invite the realization that affective studies tend not toward the creation of a new area or discipline of study, but rather toward a reorientation and critical reinterpretation (redefinition) of the objects, tools, methodologies, and theories of study within the humanities, both in their classic and new forms.

Translation: Arthur Barys 